\title{
Új bogárfajok a Naszályról
}

\author{
MERKL OTTÓ ${ }^{1} \dagger$, SZÉNÁSI VALENTIN ${ }^{2}$, PINTÉR BALÁZs ${ }^{3}$ és NÉMETH TAMÁS ${ }^{4} *$ \\ ${ }^{1}$ Magyar Természettudományi Múzeum Állattára, 1088 Budapest, Baross utca 13. \\ ${ }^{2}$ Duna-Ipoly Nemzeti Park Igazgatóság, 1021 Budapest, Költő utca 21. \\ ${ }^{3}$ Kísérleti Orvostudományi Kutatóintézet, Molekuláris Neurobiológia Kutatócsoport, 1083 Budapest, Szigony utca 43. \\ ${ }^{4}$ Magyar Agrár- és Élettudományi Egyetem Állattani és Állatökológiai Tanszék, 2100 Gödöllő, Páter Károly utca 1. \\ *E-mail: haesito@gmail.com
}

Kivonat. A tanulmány a Naszályon 2010 óta talált új bogárfajokat tartalmazza. A 11 év alatt 123 faj került elő (köztük nyolc védett), így az ismert fajok száma 1408-ra emelkedett. Az újonnan találtak között számos bogárfaj országos szinten is faunisztikai ritkaság. A recés álcsuklyásszú (Endecatomus reticulatus) Európa-szerte igen ritka, naszályi adata az ötödik bizonyított hazai elöfordulása.

Kulcsszavak: biodiverzitás, Coleoptera, HUDI20038, Magyar Természettudományi Múzeum, szaproxilofág, természetvédelem

Elfogadva: 2022.01.04.

Elektronikusan megjelent: 2022.01.14.

\section{Bevezetés}

A Naszály zoológiai kutatása a 2000-es évek elején a reneszánszát élte. Ennek egyik eredménye volt MERKL OTTÓ összefoglaló munkája 2010-ben, melyben a szerző 1285 bogárfajt sorolt fel. Az adatokon felbuzdulva sokan keresték fel a területet, és az elmúlt 11 év során a már meglévő adatok megerősítése mellett számos fajjal gazdagodott a Naszályról kimutatott bogárfajok listája. A kapott eredmények újfent bizonyítják, hogy mennyire gazdag élővilággal rendelkezik ez az országos védettséget nem élvező hegy.

\section{Anyag és módszer}

A Naszály Közép-Magyarország északi részén, a Dunakanyar szomszédságában fekszik. Közigazgatásilag döntő részben Pest megyében található, északi szegélye érinti Nógrád megyét, községhatár szerint nagyrészt Vác és Kosd, kis részben Szendehely (Katalinpuszta) fedi. Figyelembe vettük a 2010-es vizsgálati terület határait (1. ábra; PINTÉR \& TíMÁR 2010), és csak néhány esetben tértünk el attól, ha faunisztikailag országos szinten is fontos bogárfaj került elö. Ezeket külön jelöltük az enumerációban. 
A Naszály bogárfaunájáról szóló tanulmány (MERKL 2010) megjelenése óta a területen jobbára alkalomszerü gyüjtésekre került sor, részben amatőr bogarászok és természetfotósok, részben a Magyar Természettudományi Múzeum (MTM) munkatársai részéről. A Duna-Ipoly Nemzeti Park Igazgatóság 2018-ban megbízta az MTM-et „A NyugatCserhát és Naszály (HUDI20038) szaproxilofág bogarainak felmérése, különös tekintettel a Natura 2000 jelölö, védett és fokozottan védett fajokra" elnevezésü feladattal. Ennek során a Naszályon is történt gyüjtés.

A gyüjtések során az általánosan ismert módszereket alkalmaztuk. Ilyenek a nappali és éjszakai fühálózás, a kopogtatás, a rostálás, a boros csapdázás, a kinevelés, valamint az egyelés (ez utóbbi a talajon, a talajon fekvő tárgyak alatt, a növényzeten, a gombákban, az elhalt fák kérge alatt, a korhadt fákban található bogarak egyenkénti összeszedését jelenti). A gyüjtött bogárpéldányok az MTM Állattára Bogárgyüjteményében találhatók.

Az enumerációban a családok LAWRENCE \& NEWTON (1995), MERKL \& VIG (2009) és DE JONG et al. (2014) besorolását követjük, a családokon belül a fajok ábécérendben következnek egymás után. A fajok tudományos nevét minden esetben a magyar név is követi. A magyarországi bogárfauna katalógusának kéziratán e cikk első szerzője évtizedeken át dolgozott. Sajnálatos módon ez a hiánypótló mü nem jelenhetett meg, ennek ellenére jelen tanulmányban a katalógus kéziratában szereplő magyar neveket használjuk.

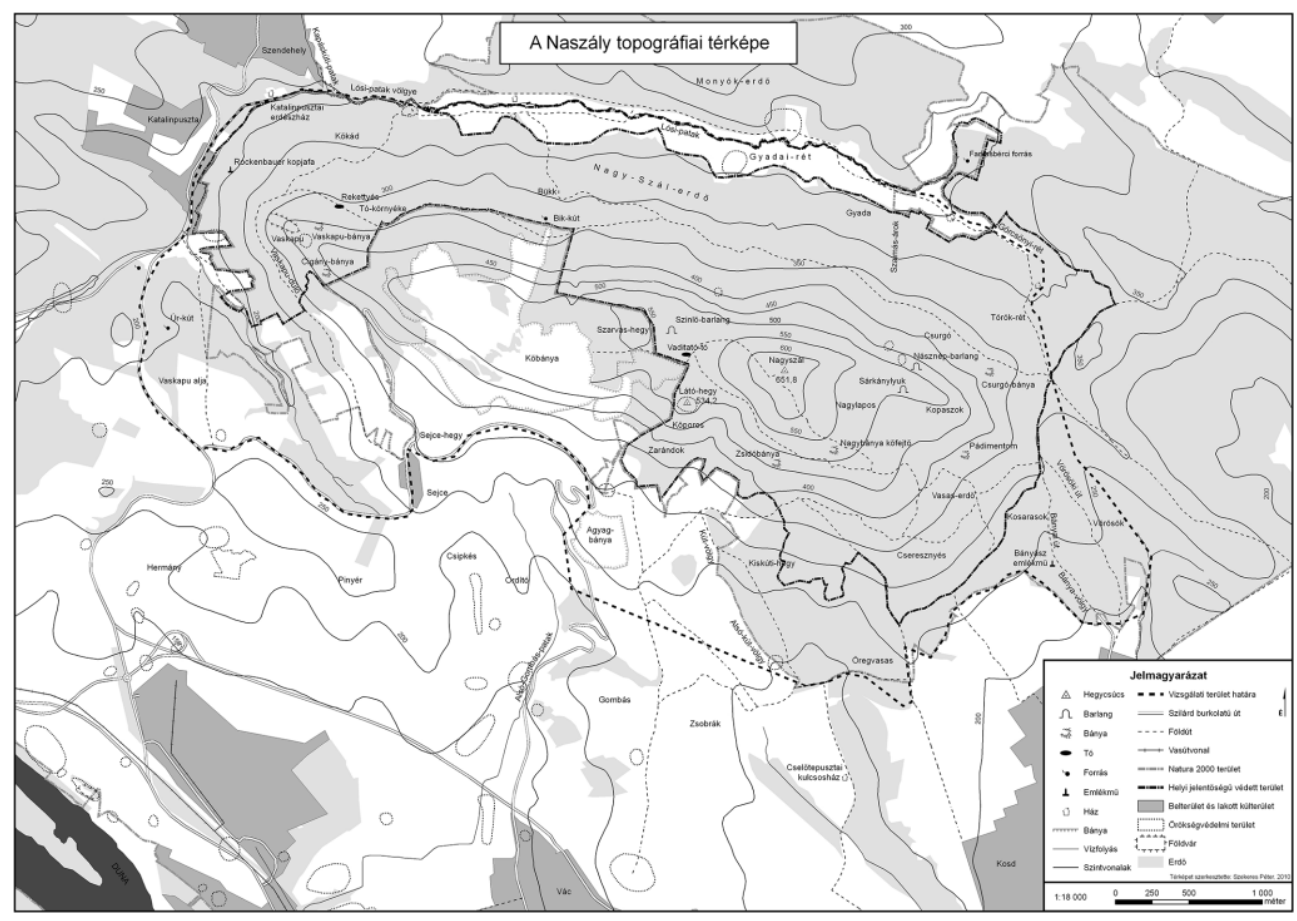

1. ábra. A Naszály kutatási területe, szaggatott vonallal (PINTÉR \& TíMÁR 2010; készítette: SzEKERES P.)

Figure 1. The research area of Naszály, its border with dashed line (PINTÉR \& TíMÁr 2010; map by P. SzeKERES) 


\section{Eredmények}

Jelen összesítés 123 olyan fajt sorol fel (köztük 8 védettet), melyek a 2010-ben megjelent cikkben nem szerepeltek (1. táblázat).

1. táblázat. A Naszályról kimutatott bogárfajok szám szerinti változása

Table 1. Change in the number of beetle species detected in Naszály Hill

\begin{tabular}{|c|c|c|}
\hline & bogarak teljes fajszáma & ebböl a védett/fokozottan védett fajok \\
\hline MERKL (2010) adatai & 1285 & $45 / 1$ \\
\hline Új adatok & 123 & 8 \\
\hline Összes & 1408 & $53 / 1$ \\
\hline
\end{tabular}

A védett fajok közül az aranyos bábrabló (Calosoma sycophanta), a ligeti futrinka (Carabus nemoralis), a selymes futrinka (Carabus convexus) és a laposorrú ormányos (Gasterocercus depressirostris) (3. ábra G) a középhegységi erdőkben általánosan elterjedt; a balkáni futrinka (Carabus montivagus) szórványosabb, de a Naszály tágabb környezetéből ismert, ezért előkerülése örvendetes, de nem meglepö; a négyfoltos pattanó (Ampedus quadrisignatus) (2. ábra B) és a tarka pikkelyespattanó (Lacon querceus) (2. ábra C) jóval ritkább, de a Naszály erdeinek állapotát ismerve megtalálásuk vörösen korhadó fában várható volt; az óriásnünüke (Meloe cicatricosus) löszgyepeken sokfelé előfordul, ám általában nem gyakori.

A 2010-es listában még 31 védett faj szerepelt (MERKL 2010), de 15 olyan bogárfaj is megtalálható az enumerációban, amely a 100/2012. (IX. 28.) VM rendelet 2. melléklete alapján azóta védettséget élvez: a mezei homokfutrinka (Cicindela campestris), a parlagi homokfutrinka (Cylindera germanica), a szörös szarvasbogár (Aesalus scarabaeoides), a kis fémesszarvasbogár (Platycerus caraboides), a nagyfejü csajkó (Lethrus apterus), a cseresznyefa-virágdíszbogár (Anthaxia candens), a redős virágdíszbogár (Anthaxia plicata), a bükkfa-díszbogár (Dicerca berolinensis), a ráncos nünüke (Meloe rugosus), az érdes nünüke (Meloe scabriusculus), a déli büzbogár (Blaps abbreviata), a kis hőscincér (Cerambyx scopolii), a nyolcpontos cincér (Saperda octopunctata), a díszes nyárfacincér (Saperda perforata) és a létracincér (Saperda scalaris). A kék pattanó (Limoniscus violaceus) a védettböl átkerült a fokozottan védett státuszba. Összesítve jelenleg a Naszályról 53 védett és egy fokozottan védett bogárfaj ismert.

$\mathrm{Az}$ újonnan kimutatott fajok közül kettőnek, a balkáni futrinkának (Carabus montivagus) (KÖDÖBÖcZ 2017) és a déli komorkának (Dircaea australis) (2. ábra H) (KONVIČKA \& MERKL 2015) van 2010 óta publikált adata a Naszályról.

Időközben egy fajról kiderült, hogy közlése téves azonosítás eredménye. A szegélyes gyümölcsfénybogár (Carpophilus marginellus MOTSCHULSKY, 1858) bizonyító példánya valójában a vállfoltos gyümölcsfénybogár (Urophorus humeralis (FABRICIUS, 1798)) képviselöje; a fajt a naszályi példány alapján NÉMETH et al. (2017) a magyar faunára újként közölték. A fajszámot tehát ez az adat nem befolyásolja.

Faunisztikai szempontból a leginkább figyelemre méltó a recés álcsuklyásszú (Endecatomus reticulatus) (2. ábra F) előfordulása. A mindössze négy fajból álló álcsuklyásszúfélék (Endecatomidae) családjának egyetlen európai képviselője nagyon ritka 
előfordulású. Bár sok európai országból jelezték, a legtöbb országból csupán egy-két adata ismert; Németországban kihaltnak tekintik. Idős, zavartalan lomberdők, főleg tölgyesek lakója. Gombafogyasztó: gazdafajként a szakirodalom az égerfa-rozsdástaplót (Inonotus radiatus), a nyírfataplót (Polyporus betulinus) és sárga gévagombát (Laetiporus sulphuraeus) említi.

WIEZIK et al. (2015) a recés álcsuklyásszú előfordulásáról számolnak be a középszlovákiai Körmöci-hegységben (Kremnické vrchy). Ott az Inonotus andersonii taplón tömegesen találták 2008-ban, 2009-ben és 2013-ban. A ritkának tartott tapló - mely ZHOU et al. (2014) szerint valójában I. krawtzewii - csertölgy halott, álló törzsein fejlődött.

Magyarországról a recés álcsuklyásszú korábbi előfordulását mindössze öt példány bizonyítja az alábbi helyekröl és adatokkal (az MTM gyüjteménye alapján): Borsod-AbaújZemplén megye: Erdőbénye (a gyüjtő és a gyüjtési idő ismeretlen, de valószínüleg a 20. század első évtizedei, 1 példány); Pest megye: Budakeszi, 1897.VI., DIENER H. (2 példány), Páty, Kopasz-hegy lába, kéreg alól, 2016.IV.2., SzÉNÁSI V. (1 példány); Veszprém megye: Fenyőfö, erdőszél, egyelés, 1979.V.19., ÁDÁM L. (1 példány).

A Naszály északi oldalán 2018-ban a szlovákiai esetekhez hasonlóan a bogár számos egyede került elő hegyi juhar (Acer pseudoplatanus) odvában növő gombáról. A gyüjtő (NÉMETH TAMÁs) a gazdafajt pisztricgombának (Polyporus squamosus) határozta, de WIEZIK et al. (2015) cikke alapján ma már nem biztos ebben. A kétséget a körülmények is fokozzák (a gomba odúban nőtt), mindenesetre a gomba nem hasonlított a WIEZIK et al. (2015) cikkében közölt gomba fotójára.

Jelen cikk lezárása előtt került elő a Naszály déli oldalának tölgyeséből az országszerte ritka, mindössze a Mátrából és a Bükkből (SzALÓKI 1993, KoVÁCS et al. 2010), a Mecsekből (HoRVATOVICH 2007), valamint a Vértesböl (KovÁCS \& NÉMETH 2010) ismert szőrös álkomorka (Tetratoma desmarestii) (3. ábra A) példánya. A késő ősztől kora tavaszig aktív bogár egyedét a könnyező rozsdástapló (Pseudoinonotus dryadeus) idős termőtestéről gyüjtötték.

A bordáshátú földiormányos (Plinthus sturmii sturmii) (3. ábra H) egyedei 2021-ben a Naszály csúcsának közelében, mezei juharok (Acer campestre) alól kerültek elő rostálással. A fajnak két régebben publikált hazai adata ismert, Börzsönyböl és Pápáról (ENDRŐDI 1963). A pápai adatot PODLUSSÁNY (2007) valószínüleg innen vehette át, munkájában a településen kívül más információt nem közöl. Börzsönyi előfordulása 2021-ben megerősítést nyert, PAULIK PÉTER Nagyorosziban, a Karajsó-hegynél fotózta le egy példányát (PAULIK 2021). A börzsönyi és a naszályi élöhely típusa nagyon hasonló. A faj tápnövénye irodalmi adatok szerint a kónya vicsorgó (Lathraea squmaria), valamint aszat- (Cirsium spp.) és útifü- (Plantago spp.) fajok (KIPPENBERG 1981). A naszályi, zárt erdei élőhelyen ezek közül a kónya vicsorgó fordul elő.

A laposszemü busaormányos (Barynotus obscurus) példányai a bordáshátú földiormányossal együtt kerültek elö, majd későbbi időpontban éjszakai hálózás során nagyobb számban is sikerült kimutatni a Látó- és Szarvashegy területéről. A közép- és magashegységi elterjedésü faj a Kárpátok és Alpok vonulatain gyakorinak mondható, hazánkban azonban a közelmúltban csak a Bakonyból (Porva: Szépalmapuszta, 2005.VII.29. talajcsapda, KUTASI CsABA; PODLUSSÁNY 2007), Esztergom környékéröl (MOLNÁR 2018) és a Börzsönyböl (leg. ILNICZKY SÁNDOR, 2020) került elő 1-1 példánya. Tápnövénye nem ismert. 


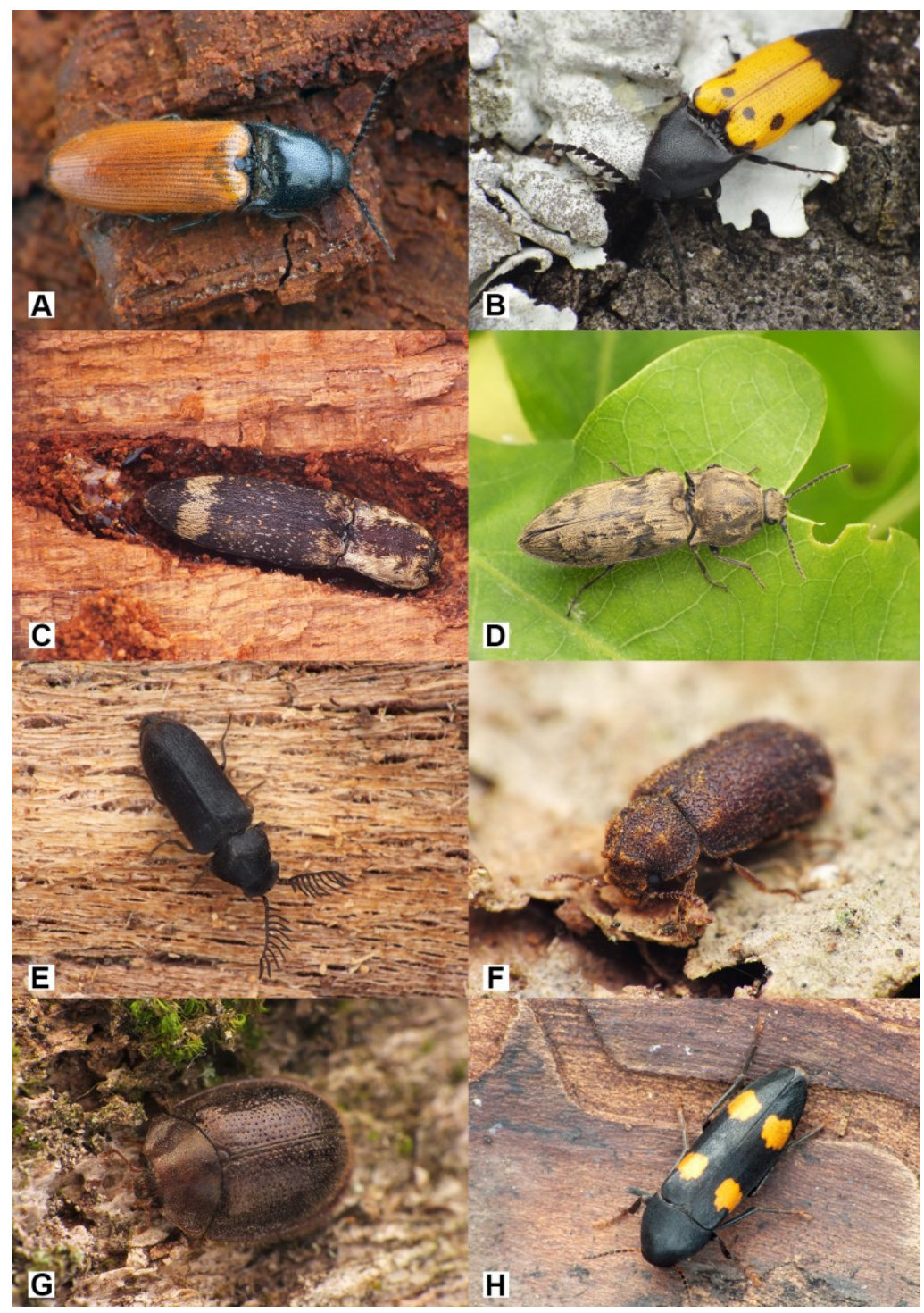

2. ábra. Naszályra új bogárfajok I. A: Ampedus nigroflavus (GOEZE, 1777) - feketesárga pattanó, B: Ampedus quadrisignatus (GYLLENHAL, 1817) - négyfoltos pattanó, C: Lacon querceus (HERBST, 1784) - tarka pikkelyespattanó, D: Prosternon chrysocomum (GERMAR, 1843) - nagy kockáspattanó, E: Pseudoptilinus fissicollis (REITTER, 1877) - hársfúró álszú, F: Endecatomus reticulatus (HERBST, 1793) - recés álcsuklyásszú, G: Thymalus limbatus (FABRICIUS, 1787) - bronzfényü korongbogár, H: Dircaea australis (FAIRMAIRE, 1856) - déli komorka. Az ábrák nem méretarányosak (fotók: NÉMETH T.).

Figure 2. New beetle species for the Naszály Hill I. A: Ampedus nigroflavus (GoEZE, 1777), B: Ampedus quadrisignatus (GYLlenhal, 1817), C: Lacon querceus (HERBST, 1784), D: Prosternon chrysocomum (GERMAR, 1843), E: Pseudoptilinus fissicollis (REITTER, 1877), F: Endecatomus reticulatus (HERBST, 1793), G: Thymalus limbatus (FABRICIUS, 1787), H: Dircaea australis (FAIRMAIRE, 1856). Figures are not to scale (photos by T. NÉMETH). 


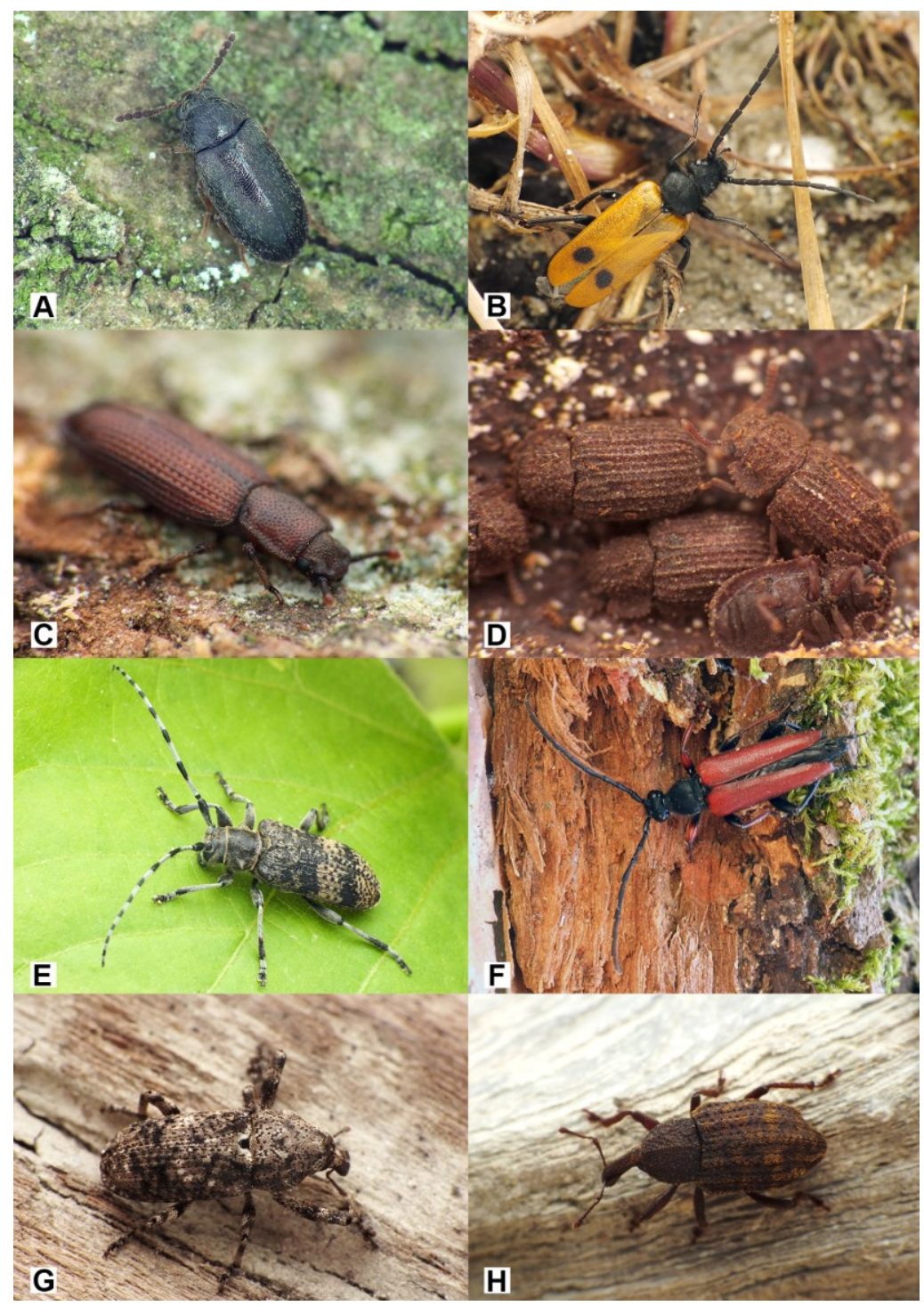

3. ábra. Naszályra új bogárfajok II. A: Tetratoma desmarestii LATREILLE, 1807 - szőrös álkomorka, B: Apalus bimaculatus (LinNAEus, 1760) - kétfoltos élösdibogár, C: Pycnomerus terebrans (A. G.

OLIVIER, 1790) - bordás héjbogár, D: Eledonoprius armatus (PANZER, 1799) - érdes taplóbogár, E: Oplosia cinerea (MULSANT, 1839) - foltos hárscincér, F: Stictoleptura erythroptera (HAGENBACH, 1822) - bordó virágcincér, G: Gasterocercus depressirostris (FABRICIUS, 1792) - laposorrú ormányos, H: Plinthus sturmii sturmii GERMAR, 1818 - bordáshátú földiormányos. Az ábrák nem méretarányosak (fotók: NÉMETH T.).

Figure 3. New beetle species for the Naszály Hill II. A: Tetratoma desmarestii LATREILLE, 1807, B: Apalus bimaculatus (Linnaeus, 1760), C: Pycnomerus terebrans (A. G. Olivier, 1790), D: Eledonoprius armatus (PANZER, 1799), E: Oplosia cinerea (MuLSANT, 1839), F: Stictoleptura erythroptera (HAGENBACH, 1822), G: Gasterocercus depressirostris (FABRICIUS, 1792), H: Plinthus sturmii sturmii GERMAR, 1818. Figures are not to scale (photos by T. NÉMETH). 
A csupasz gyepormányos (Brachysomus subnudus) a rövid életü, röpképtelen, így sok endemikus fajt magába foglaló Brachysomus genusz egyik ritka hazai tagja. Magyarországi előfordulása a nyugati határvidékre (főként a Kőszegi- és a Soproni-hegység területére) korlátozódik, egyetlen Győr-Moson-Sopron megyei adata ismert Koroncó környékéről 2021-ből (leg. SZELENCZEY BÉLA), így a faj naszályi előfordulása mindenképpen izgalmas kérdéseket vet fel hazai areáját illetően. Tápnövénye és életmódja ismeretlen, a rövid életü imágók májustól július közepéig találhatóak üdébb, bükkös és gyertyános-tölgyes erdőállományok gyepszintjében.

A szürke gyalogormányos (Cirrorhynchus kelecsenyii) kárpáti endemizmus, Románia, Szlovákia és Magyarország területéről ismert. Hazánkban rendkívül ritka, az Aggtelekikarsztvidékröl (Martonyi) ismert egy 1987-es adata (MTM gyüjtemény, 1987.VI.15., gyüjtő nem ismert). A naszályi adata az ismert előfordulási helytől mintegy $140 \mathrm{~km}$-re fekszik, így valószínüleg a köztes középhegységi területeken is valószínüsíthető előfordulása. Kimutatását éjszakai életmódja nehezíti. Tápnövénye nem ismert, de a nagy fajszámú és főként balkáni elterjedésủ genusz számos faja erősen polifág.

\section{Enumeráció}

\section{Carabidae - Futóbogárfélék}

Calosoma sycophanta (LINNAEUS, 1758) - aranyos bábrabló - Vác, Naszály, Szalmásárok, 2018.V.23., GraBANT A. és MERKL O. Védett.

Carabus convexus FABRICIUS, 1775 - selymes futrinka - Kosd, Bánya-völgy, 2021.III.3., PinTÉr B.; Vác, Naszály, Kopaszok, 2021.III.3., PinTÉR B.; Vác, Naszály, Nagy-Szál-erdő, 2018.V.23., NÉMETH T. és SzABÓ Cs. Védett.

Carabus montivagus PALLIARDI, 1825 - balkáni futrinka - Vác, Naszály, kertek közötti földút, 1989.IV.5., HEGYESSY G. (KÖDÖBÖCZ 2017). Védett.

Carabus nemoralis O. F. MÜLlER, 1764 - ligeti futrinka - Kosd, Bánya-hegy, 2018.V.2., Grabant A. és Merkl O.; Vác, Naszály, Nagy-Szál-erdö, 2014.III.31., PinTÉr B.; Vác, Naszály, Nagy-Szál-erdő, 2018.V.23., NÉMETH T. és SzABÓ Cs. Védett.

\section{Silphidae - Dögbogárfélék}

Silpha carinata HERBST, 1783 - karimás dögbogár - Vác, Gyadai-rét, 2020.VI.8., PINTÉR B.

Staphylinidae - Holyvafélék

Batrisodes delaporti (AUBÉ, 1833) - púposfejü tapogatósbogár - Vác, Gyadai tanösvény, függőhíd környéke, Lasius sp. fészkéből rostálva, 2016.VIII.2., SERES G. és ROMSAUER J.

Batrisodes venustus (AUBÉ, 1833) - tüskésnyakú tapogatósbogár - Vác, Gyadai tanösvény, függőhíd környéke, Lasius sp. fészkéből rostálva, 2016.VIII.2., SERES G. és ROMSAUER J.; Vác, Naszály, Vaditató-tó környéke, Lasius sp. fészkéböl rostálva, 2020.V.28., SERES G. 
Brachygluta sinuata (AUBÉ, 1833) - öblöslemezü tapogatósbogár - Vác, Gyadai-rét, kaszálórét, rostálás, 2009.IV.2., FÁNI Zs., KOTÁN A. és NÉMETH T.; Vác, Naszály, NagySzál-erdő, törmeléklejtő-erdő, rostálás, 2009.IV.2., FÁNI Zs., KOTÁN A. és NÉMETH T.

Bryaxis bulbifer (REICHENBACH, 1816) - simanyakú tapogatósbogár - Vác, Gyadai-rét, Lósi-patak medre, rostálás, 2016.VIII.2., SERES G. és ROMSAUER J.

Bryaxis carinula (REY, 1888) - egyeneshomlokú tapogatósbogár - Vác, Gyadai-rét, Lósi-patak medre, rostálás, 2016.VIII.2., SERES G. és ROMSAUER J.

Euconnus pragensis MACHULKA, 1923 - prágai gödörkésbogár - Vác, Naszály, Vaditató-tó környéke, Lasius sp. fészkéböl rostálva, 2020.V.28., SERES G.

Euconnus pubicollis (P.W.J. MÜLLER \& KUNZE, 1822) - szörösnyakú gödörkésbogár Vác, Gyadai tanösvény, függőhíd környéke, rostálás, 2016.VIII.2., SERES G. és ROMSAUER J.; Vác, Naszály, Vaditató-tó környéke, rostálás, 2020.V.28., SERES G.

Euplectus brunneus (GRIMMER 1841) - sötétbarna tapogatósbogár - Vác, Naszály, Vaditató-tó környéke, rostálás, 2013.IX.29., ROMSAUER J.

Euplectus kirbyi kirbyi DENNY, 1825 - nyugati Kirby-tapogatósbogár - Vác, Naszály, déli oldal, autóshálózás délután, 2007.IV.14., MERKL O., KOTÁN A. és RAHMÉ N.

Thoracophorus corticinus (MOTSCHULSKY 1837) - hangyakedvelő vértesholyva - Vác, Naszály, déli oldal, 2016.IX.2., Lasius sp. fészekből rostálva, ROMSAUER J.

Tychus niger (PAYKULL 1800) - fekete tapogatósbogár - Vác, Gyadai-rét, Lósi-patak medre, rostálás, 2016.VIII.2., SERES G. és ROMSAUER J.

\section{Histeridae - Sutabogárfélék}

Abraeus perpusillus (MARSHAM, 1802) - közönséges gömbsutabogár - Vác, Naszály, Vaditató-tó környéke, rostálás, 2020.V.28., SERES G.

Margarinotus merdarius (HOFFMANN, 1803) - odúlakó sutabogár - Vác, Naszály, Nagy-Szál-erdő, bükkodúból, 2013.III.3., KoTÁN A., NEMES P. és NÉMETH T.

Plegaderus caesus (HERBST, 1791) - közönséges vágottsutabogár - Vác, Naszály, Vaditató-tó környéke, rostálás, 2020.V.28., SERES G.

Teretrius fabricii MAZUR, 1972 - éji sutabogár - Vác, Naszály, fühálózás, 1996.V.19., SZALÓKI D.

\section{Eucnemidae - Tövisnyakúbogár-félék}

Microrhagus lepidus (RoSENHAUER, 1847) - csinos tövisnyakúbogár - Vác, Naszály, Nagy-Szál-erdő, törmeléklejtő, aljnövényzetről hálózva, 2011.VI.21., NÉMETH T. és VÖRÖS J.; Vác, Naszály, Nagy-Szál-erdő, 2018.V.23, NÉMETH T. és SzABÓ Cs.

Microrhagus pygmaeus (FABRICIUS, 1792) - apró tövisnyakúbogár - Vác, Naszály, Nagy-Szál-erdő, törmeléklejtő, aljnövényzetről hálózva, 2011.VI.21., NÉMETH T. és VÖRÖS J.

\section{Elateridae - Pattanóbogár-félék}

Agriotes lineatus (LINNAEUS, 1767) - vetési pattanó - Vác, Gyadai-rét, 2020.IV.30., PINTÉR B. 
Ampedus nigerrimus (LACORDAIRE, 1835) - fekete pattanó - Vác, Naszály, Nagy-Szálerdő, tölgyodúból, 2011.X.13., NÉMETH T. és KOTÁN A.

Ampedus nigroflavus (GOEZE, 1777) - feketesárga pattanó (2. ábra A) -Vác, Gyadai-rét, patakvölgy, egyelés, 2011.IV.22., NÉMETH T. és VÖRÖS J.

Ampedus praeustus (FABRICIUS, 1792) - rötvörös pattanó - Vác, Naszály, Nagy-Szálerdő, korhadt tölgyből, 2017.III.11., NEMES P. és NÉMETH T.

Ampedus quadrisignatus (GYLLENHAL, 1817) - négyfoltos pattanó (2. ábra B) - Vác, Naszály, Nagy-Szál-erdő, korhadt kőrisből nevelve, 2017.IV.1., KOTÁN A., NÉMETH T. és SzÉNÁSI V.; Vác, Naszály, Nagy-Szál-erdő, 2018.V.23, NÉMETH T. és SzABÓ Cs.; Vác, Naszály, Nagy-Szál-erdő, korhadt kőrisből, 2021.V.8., NEMES P. és NÉMETH T. Védett.

Ampedus sanguineus (LINNAEUS, 1758) - vérvörös pattanó - Vác, Naszály, Nagy-Szálerdő, korhadt fenyőböl, 2018.IV.1., NÉMETH T.

Athous austriacus DESBROCHERS des LOGES, 1873 - osztrák pattanó - Vác, Naszály, Nagy-Szál-erdő, aljnövényzetröl hálózva, 2011.VI.21., NÉMETH T. és VÖRÖS J.

Lacon querceus (HERBST, 1784) - tarka pikkelyespattanó (2. ábra C) - Vác, Naszály, Bükk, korhadt tölgyből, 2017.III.11., NEMES P. és NÉMETH T. Védett.

Prosternon chrysocomum (GERMAR, 1843) - nagy kockáspattanó (2. ábra D) - Vác, Naszály, Cseresznyés, tölgyes, boroscsapda, 2013.VII.3., KOTÁN A., NÉMETH T. és SERES G.; Vác, Naszály, Szarvashegy, 2021.V.24., KoTÁN A.

Nosodendridae - Falébogárfélék

Nosodendron fasciculare (A.G. OLIVIER, 1790) - európai falébogár - Kosd, Görcsöny, 2018.V.23., GRABANT A. és MERKL O.

Bostrichidae - Csuklyásszúfélék

Xylopertha retusa (A.G. OLIVIER, 1790) - fekete csuklyásszú - Vác, Naszály, Látóhegy, hársas-körises törmeléklejtő, kinevelés, 2013.V.7., NÉMETH T.

Ptinidae - Álszúfélék

Pseudoptilinus fissicollis (REITTER, 1877) - hársfúró álszú (2. ábra E) - Vác, Naszály, Nagy-Szál-erdö, 2018.V.23., NÉMETH T. és SzABÓ Cs.

Ptinus rufipes A.G. OLIVIER, 1790 - vöröslábú tolvajbogár - Vác, Naszály, Nagy-Szálerdő, 2018.V.23., NÉMETH T. és SzABÓ Cs.; Vác, Naszály, Szarvashegy, 2021.V.24., NÉMETH T.

Ptinus schlerethi (REITTER, 1884) - bundásnyakú tolvajbogár - Vác, Naszály, NagySzál-erdő, hársas-kőrises törmeléklejtő, kopogtatás, 2013.V.6., NÉMETH T.

Ptinus variegatus P. Rossi, 1792 - tarka tolvajbogár - Vác, Naszály, Látó-hegy, kopogtatás, 2014.III.30., SzÉNÁSI V.

\section{Endecatomidae - Álcsuklyásszúfélék}

Endecatomus reticulatus (HERBST, 1793) - recés álcsuklyásszú (2. ábra F) - Vác, Naszály, Nagy-Szál-erdő, hegyi juhar odvából, Polyporus squamosus-ról, 2018.V.23., NÉMETH T. és SZABÓ CS. 
Trogossitidae - Korongbogár-félék

Thymalus limbatus (FABRICIUS, 1787) - bronzfényü korongbogár (2. ábra G) - Vác, Naszály, Nagy-Szál-erdő, 2018.V.8., NÉMETH T. és SzABÓ CS.

$$
\text { Erotylidae - Tarbogárfélék }
$$

Triplax lacordairii CROTCH, 1870 - szegélyesnyakú tarbogár - Vác, Naszály, NagySzál-erdő, hársas-bükkös, kopogtatás, egyelés, 2011.VI.21., NÉMETH T. és VÖRÖS J.

Mycetophagidae - Gombabogárfélék

Mycetophagus multipunctatus FABRICIUS, 1792 - sokpettyes gombabogár - Vác, Naszály, Nagy-Szál-erdő, 2018.V.23., NÉMETH T. és SzABÓ CS.

Mycetophagus quadriguttatus P.W.J. MÜLLER, 1821 - domború gombabogár - Vác, Naszály, északi oldal, korhadt tölgyböl, 2017.III.4., NÉMETH T. és NEMES P.; Vác, Naszály, Nagy-Szál-erdő, 2018.V.23., NÉMETH T. és SzABÓ Cs.

Ciidae - Taplószúfélék

Orthocis lucasi (ABEILLE de PERRIN, 1874) - szélesnyakú taplószú - Vác, Naszály, bükkös, száraz ágakról, 2005.V.14., MERKL O.

\section{Melandryidae - Komorkafélék}

Dircaea australis (FAIRMAIRE, 1856) - déli komorka (2. ábra H) - Kosd, Bánya-hegy, 2018.V.2., GRABANT A. és MERKL O.; Vác, Naszály, Nagy-Szál-erdő, bükkös, gombás ágról kopogtatva, 2013.VII.3., KotÁn A., NÉMETH T. és SERES G. (KonviČKA \& MERKL 2015); Vác, Naszály, Nagy-Szál-erdő, 2018.V.8., NÉMETH T. és SzABÓ Cs.; Vác, Naszály, Nagy-Szál-erdő, 2018.V.23., GRABANT A. és MERKL O.

Melandrya caraboides (LINNAEUS, 1761) - fémkék komorka - Vác, Naszály, NagySzál-erdö, 2018.V.23., NÉMETH T. és SzABÓ CS.

Tetratomidae - Álkomorkafélék

Tetratoma desmarestii LATREILlE, 1807 - szőrös álkomorka (3. ábra A) - Vác, Naszály, Nagy-Szál-erdő, cseres-tölgyes, Pseudoinonotus dryadeus-ról, 2021.XI.1., NÉMETH T.

\section{Meloidae - Hólyaghúzófélék}

Apalus bimaculatus (LINNAEUS, 1760) - kétfoltos élősdibogár (3. ábra B) - Vác, Lósipatak partja, 2021.III.15., NEMES P. és NÉMETH T.

Apalus bipunctatus GERMAR, 1817 - mezei élősdibogár - Vác, Lósi-patak partja, 2021.III.13., PALAGA M. (PAlaga 2021).

Meloe cicatricosus LEACH, 1815 - óriásnünüke - Vác, 2021.V.8., Vác, Alsó-kút-völgy, NeMES P. és NÉMETH T.; Vác, Zarándok, 2021.V.18., PinTÉr B. és SCHMOTZER A. Védett.

Megjegyzés: Mindkét Apalus-faj a mintaterület határán kívülröl, de ahhoz nagyon közelröl, kb. 100-200 méterre került elő. 
Zopheridae - Fahéjbogárfélék

Pycnomerus terebrans (A.G. OLIVIER, 1790) - bordás héjbogár (3. ábra C) - Vác, Naszály, Nagy-Szál-erdő, 2018.V.8., NÉMETH T. és SzABÓ CS.

Synchita humeralis (FABRICIUS, 1792) - vállfoltos héjbogár - Kosd, Bánya-hegy, 2018.V.2., Grabant A. és MerkL O.; Vác, Naszály, Nagy-Szál-erdö, 2018.V.23., NÉMETH T. és SZABÓ CS.

Synchita variegata HellWIG, 1792 - tarka héjbogár - Vác, Naszály, Nagy-Szál-erdő, kopogtatás, 2013.V.6., NÉMETH T.

Tenebrionidae - Gyászbogárfélék

Eledonoprius armatus (PANZER, 1799) - érdes taplóbogár (3. ábra D) - Vác, Naszály, Látó-hegy, molyhos tölgyes, kopogtatás, 2013.V.6., NÉMETH T.

Mycetochara axillaris (PAYKULL, 1799) - fényes taplász - Vác, Naszály, Nagy-Szálerdö, 2018.V.23., NÉMETH T. és SZABÓ CS.

Palorus depressus (FABRICIUS, 1790) - szögleteshomlokú kislisztbogár - Kosd, Bányavölgy, 2018.V.2., NÉMETH T. és SZABÓ CS.

Pentaphyllus testaceus (HellWIG, 1792) - kis korhadékbogár - Kosd, Bánya-völgy, 2018.V.2., NÉMETH T. és SzABÓ Cs.; Vác, Naszály, Nagy-Szál-erdő, 2018.V.8., NÉMETH T. és SZABÓ Cs.

Uloma culinaris (LINNAEUS, 1758) - nagy rágványbogár - Vác, Naszály, Nagy-Szálerdő, 2018.V.8., NÉMETH T. és SZABÓ Cs.

$$
\text { Salpingidae - Álormányosfélék }
$$

Lissodema cursor (GYLLENHAL, 1813) - sokfogú álormányos - Vác, Naszály, NagySzál-erdö, 2018.V.23., NÉMETH T. és SZABÓ CS.

\section{Cerambycidae - Cincérfélék}

Grammoptera abdominalis (STEPHENS, 1831) - fekete galagonyacincér - Vác, Naszály, Látó-hegy, melegkedvelö tölgyes, kopogtatás, 2010.V.23., KOTÁN A.

Oplosia cinerea (MULSANT, 1839) - foltos hárscincér (3. ábra E) - Kosd, Csurgó, hárságakról kopogtatva, 2018.V.23., GRABANT A. és MERKL O.; Kosd, Görcsöny, hárságakról kopogtatva, 2018.V.23., GrABANT A. és MERKL O.; Vác, Naszály, Nagy-Szál-erdő, hársaskőrises törmeléklejtő, kinevelés, 2013.V.7., NÉMETH T.; Vác, Naszály, Nagy-Szál-erdő, 2013.VII.3., NÉmETH T. és KotÁn A.; Vác, Szarvashegy, 2021.V.24., KotÁN A., NÉMETH T. és SZÉNÁSI V.

Stictoleptura erythroptera (HAGENBACH, 1822) - bordó virágcincér (3. ábra F) - Vác, Naszály, Nagy-Szál-erdő, hársfa odvából egyelve, 2008.IV.14., KOTÁN A.

Tetropium castaneum (LINNAEUS, 1758) - romboló fenyőcincér - Kosd, Csurgó, 2018.V.23., Grabant A. és MerkL O.

\section{Chrysomelidae - Levélbogárfélék}

Chrysolina oricalcia (O.F. MüLLER, 1776) - változékony levelész - Vác, Naszály, Nagy-Szál-erdö, 2018.V.23., NÉMETH T. 
Chrysomela cuprea FABRICIUS, 1775 - fémes füzlevelész - Vác, Gyadai-rét, füzfákról, 2018.V.23., MERKL O.; Vác, Naszály, Nagy-Szál-erdő, 2018.V.23., NÉMETH T.

Chrysomela vigintipunctata (SCOPOLI, 1763) - húszfoltos füzlevelész - Vác, Gyadairét, füzfákról, 2018.V.23., MERKL O.

Labidostomis axillaris (LACORDAIRE, 1848) - fényesnyakú zsákbogár - Vác, Kútvölgy dülö, fühálózás 2021.VI.15., KÖRMENDY Z. (KÖRMENDY 2021a).

Anthribidae - Orrosbogárfélék

Pseudeuparius sepicola (FABRICIUS, 1792) - hatdudoros orrosbogár - Kosd, Görcsöny, 2018.V.23., GRABANT A. és MERKL O.; Vác, Naszály, Látó-hegy, 2021.V.24., NÉMETH T.

\section{Attelabidae - Eszelényfélék}

Involvulus icosandriae icosandriae (SCOPOLI, 1763) - hajtástörő eszelény - Vác, Naszály, Látó-hegy, kopogtatás, 2011.IV.9., 2014.III.30., SzÉNÁSI V.

Neocoenorrhinus interpunctatus (STEPHENS, 1831) - levéléreszelény - Vác, Naszály, sejcei gyümölcsös, kopogtatás, 2021.V.24., SzÉNÁSI V.

\section{Brentidae - Pálcaormányos-félék}

Ceratapion austriacum (WAGNER, 1904) - osztrák cickányormányos - Vác, Naszály, Látó-hegy, fühálózás, 2011.V.21., SzÉNÁSI V.

Cyanapion afer (GYLLENHAL, 1833) - pontozottfejü cickányormányos - Vác, Gyadairét, fühálózás, 2010.IV.27., SzÉNÁSI V.

Helianthemapion aciculare (GERMAR, 1817) - napvirág-cickányormányos - Vác, Naszály, Látó-hegy, fühálózás, 2011.IV.9., SzÉNÁSI V.

Ischnopterapion aeneomicans (WENCKER, 1864) - erdőszéli cickányormányos - Vác, Naszály, sejcei gyümölcsös, fühálózás, 2021.VI.18., SzÉNÁSI V.

Perapion violaceum violaceum (KIRBY, 1808) - sóska-cickányormányos - Vác, Gyadairét, fúhálózás, 2010.IV.27., SzÉNÁSI V.

Protapion gracilipes (DIETRICH, 1857) - piroscsápú cickányormányos - Vác, Naszály, sejcei gyümölcsös, fühálózás, 2021.VI.18., SzÉNÁSI V.

Protapion varipes (GERMAR, 1817) - görbelábú cickányormányos - Vác, Naszály, Látóhegy, kopogtatás, 2011.IV.9., SzÉNÁSI V.

Squamapion elongatum (GERMAR, 1817) - zsálya-cickányormányos - Vác, Gyadai-rét, fühálózás, 2010.IV.27., SzÉNÁSI V.

$$
\text { Curculionidae - Ormányosbogár-félék }
$$

Acallocrates colonnellii BAHR, 2003 - karcsútorú zártormányúbogár - Vác, Naszály, Látó-hegy, kopogtatás, 2011.V.21., SzÉNÁsI V.; Vác, Naszály, Nagy-Szál-erdő, rostálás, 2013.V.6., 2017.IV.1., SZÉNÁSI V.

Anthonomus pyri GYLLENHAL, 1835 - pompás rügylikasztó - Vác, Naszály, Alsó-kútvölgy, kopogtatás, 2007.V.20., NÁDAI L.; Vác, Naszály, sejcei gyümölcsös, kopogtatás, 2011.V.21., SZÉNÁSI V. 
Anthonomus rectirostris (LINNAEUS, 1758) - meggymaglikasztó - Vác, Gyadai-rét, kopogtatás, 2010.IV.27., SZÉNÁSI V.

Barynotus obscurus (FABRICIUS, 1775) - laposszemü busaormányos - Vác, Naszály, Látó-hegy, éjszakai fühálózás, 2021.VI.18., SzÉNÁSI V.; Szarvashegy, rostálás, éjszakai fühálózás, 2021.V.24., 2021.VI.18., SzÉNÁSI V.

Brachysomus setiger (GYLLENHAL, 1840) - vastagcsápú gyepormányos - Vác, Naszály, kőbánya környéke, rostálás, 2019.V.18., SzÉNÁSI V.; Vác, Naszály, sejcei gyümölcsös, rostálás, 2019.V.18., SzÉNÁSI V.

Brachysomus subnudus (SEIDLITZ, 1868) - csupasz gyepormányos - Vác, Naszály, Szarvashegy rostálás, 2021.V.24., KOTÁN A.

Cathormiocerus aristatus (GYLLENHAL, 1827) - szálkás éjiormányos - Vác, Naszály, kőbánya környéke, rostálás, 2019.V.18., SzÉNÁSI V.

Ceutorhynchus nigritulus SCHULTZE, 1897 - ikravirág-ceutormányos - Vác, Gyadai-rét, fühálózás, 2010.IV.27., SzÉNÁSI V.

Ceutorhynchus scrobicollis NERESHEIMER \& WAGNER, 1924 - gödröstorú ceutormányos - Vác, Naszály, Nagy-Szál-erdö, hársas-bükkös, kopogtatás, egyelés, 2011.VI.21., NÉMETH T. és VÖRÖS J.

Ceutorhynchus talickyi KOROTYAEV, 1980 - pusztai ceutormányos - Vác, Naszály, Látó-hegy, fühálózás, 2021.V.24., SzÉNÁSI V.

Cirrorhynchus kelecsenyii (J. FRIVALDSZKY, 1892) - szürke gyalogormányos - Vác, Naszály, Látó-hegy, kopogtatás, éjszakai fühálózás, 2021.V.24. és 2021.VI.18., KoTÁN A. és SzÉNÁSI V.; Vác, Naszály, Szarvashegy, éjszakai fühálózás, 2021.VI.18., SzÉNÁSI V.

Cycloderes pilosulus (HERBST, 1795) - pikkelyeslábú ormányos - Vác, Naszály, sejcei gyümölcsös, fühálózás, 2021.V.24., SzÉNÁSI V.

Curculio propinquus (DESBROCHERS des LOGES, 1868) - halvány zsuzsóka - Vác, Gyadai-rét, 2019.IX.2., PINTÉR B. és SzABÓKY Cs.; Vác, Naszály, kőbánya környéke, kopogtatás, 2020.IX.3., SZÉNÁSI V.

Curculio villosus (J. FRIVALDSZKY, 1892) - gubacslakó zsuzsóka - Vác, Naszály, Nagybánya-kő, kopogtatás, 2021.V.24., KOTÁN A.

Datonychus paszlavszkyi (KUTHY, 1890) - fehérfoltos zsályaormányos - Vác, Gyadairét, fühálózás, 2010.IV.27., SzÉNÁsI V.

Donus oxalis (HERBST, 1795) - sóska-gubósormányos - Vác, Naszály, Nagy-Szál-erdő, hársas-bükkös, kopogtatás, egyelés, 2011.VI.21., NÉMETH T. és VÖRÖS J.

Gasterocercus depressirostris (FABRICIUS, 1792) - laposorrú ormányos (3. ábra G) Vác, Naszály, Nagy-Szál-erdő, egyelés, 2017.IV.1., SzÉNÁSI V. Védett.

Gymnetron rotundicolle GYLLENHAL, 1838 - fémesszőrü veronikaormányos - Vác, Naszály, Látó-hegy fühálózás, 2021.V.24., KOTÁN A.

Hylobius abietis (LinNAEUS, 1758) - nagy fenyvesormányos - Vác, Naszály, Szarvashegy, egyelés, 2021.V.8., NÉMETH T.

Hypera contaminata (HERBST, 1795) - homályos pikkelyesormányos - Vác, Naszály, Nagy-Szál-erdő, fühálózás, 2008.IV.26., SzÉNÁSI V. 
Hypera denominanda (CAPIOMONT, 1868) - zömök pikkelyesormányos - Vác, Gyadairét, fühálózás, 2010.IV.27., SZÉNÁSI V.

Hypera miles (PAYKULL, 1792) - lednek-pikkelyesormányos - Vác, Gyadai-rét, fühálózás, 2010.IV.27., SzÉNÁSI V.

Hypera plantaginis (DE GEER, 1775) - útifü-pikkelyesormányos - Vác, Naszály, NagySzál-erdő, fühálózás, 2017.IV.1., KOTÁN A.

Hypera rumicis (LINNAEUS, 1758) - sóska-pikkelyesormányos - Vác, Gyadai-rét, fühálózás, 2010.IV.27., SZÉNÁSI V.

Hypera suspiciosa (HERBST, 1795) - lednek-gubósormányos - Vác, Gyadai-rét, fühálózás, 2010.IV.27., SZÉNÁSI V.

Hypera venusta (FABRICIUS, 1781) - bíborhere-pikkelyesormányos - Vác, Gyadai-rét, fühálózás, 2010.IV.27., SzÉNÁSI V.

Leiosoma cribrum (GYLLENHAL, 1834) - violabarkócska - Vác, Naszály, Szarvashegy, fühálózás, rostálás, 2021.V.24., KOTÁN A. és SzÉNÁSI V.

Lepyrus capucinus (SCHALLER, 1783) - pettyes füzormányos - Vác, Gyadai-rét, fühálózás, 2017.IV.1., KOTÁN A.

Magdalis ruficornis (LINNAEUS, 1758) - sárgacsápú magdolnaormányos - Vác, Naszály, sejcei gyümölcsös, kopogtatás, 2011.V.21., SzÉNÁSI V.

Mecinus janthinifornis TOŠEVSKI \& CALDARA, 2011 - déli gyújtoványfü-ormányos Vác, Naszály, kőbánya, egyelés, 2019.V.18., SzÉNÁSI V.

Minyops variolosus (FABRICIUS, 1775) - nyugati bordásormányos - Vác, Kis Sejce, egyelés, 2019.IV.8., SzÉNÁSI V. (SZÉNÁSI 2020). A vizsgálati területen kívül, de annak határához közel.

Mogulones pallidicornis (GOUGELET \& H. BRISOUT de BARNEVILLE, 1860) - barna tarkaormányos - Vác, Gyadai-rét, fühálózás, 2010.IV.27., SzÉNÁSI V.

Mononychus punctumalbum (HERBST, 1784) - egykarmú nősziromormányos - Vác, Naszály, Látó-hegy, fühálózás, 2011.V.21., SzÉNÁSI V.

Oedecnemidius varius (BRULLÉ, 1832) - tarka tölgyormányos - Vác, Naszály, Látóhegy, sejcei gyümölcsös, kopogtatás, 2021.V.24., KOTÁN A., NÉMETH T., és SzÉNÁSI V.; Vác, Kútvölgy dűlő, kopogtatás 2021.VI.15, KÖRMENDY Z. (KÖRMENDY 2021b).

Otiorhynchus coarctatus STIERLIN, 1861 - ráspolyostorú gyalogormányos - Vác, Naszály, Szarvashegy, kopogtatás, 2021.V.24., NÉMETH T.

Otiorhynchus labilis STIERLIN, 1883 - keskenyormányú gyalogormányos - Vác, Naszály, Nagy-Szál-erdő, kopogtatás, 2013.V.6., NÉMETH T.

Otiorhynchus rugosostriatus (GOEZE, 1777) - szamóca-gyalogormányos - Vác, Naszály, Sejce, rostálás, 2019.V.1., SzÉNÁSI V.

Phloeophagus thomsoni (GRILL, 1898) - barázdás szúormányos - Vác, Naszály, egyelés, 2008.X.16., NÉMETH T.

Pissodes castaneus (DEGEER, 1775) - fehérfoltos fenyőbogár - Vác, Naszály, Látóhegy, kopogtatás, 2011.IV.9., SzÉNÁsI V. 
Plinthus sturmii sturmii GERMAR, 1818 - bordáshátú földiormányos (3. ábra $\mathrm{H}$ ) - Vác, Naszály, Szarvashegy, egyelés, rostálás, 2021.V.8. és 2021.V.24., KOTÁN A., NEMES P., NÉMETH T. és SZÉNÁSI V.

Ranunculiphilus faeculentus (GYLLENHAL, 1837) - szarkalábormányos - Vác, Naszály, Vaskapu környéke, fühálózás, 2017.V.8., SzÉNÁSI V.

Rhinusa florum (RÜBSAAMEN, 1895) - kerekded gyújtoványfü-ormányos - Vác, Naszály, Sejce, fühálózás, 2019.VII.5., SZÉNÁSI V.

Sciaphilus asperatus (BONSDORFF, 1785) - árnyékkereső ormányos - Vác, Naszály, Nagy-Szál-erdő, hársas-bükkös, kopogtatás, egyelés, 2011.VI.21., NÉMETH T. és VÖRÖs J.

Sitona suturalis STEPHENS, 1831 - fémes csipkézőbogár - Vác, Gyadai-rét, fühálózás, 2010.IV.27., SZÉNÁSI V.

Smicronyx coecus (REICH, 1797) - egykarmú arankaormányos - Vác, Naszály, sejcei gyümölcsös, fühálózás, 2021.VI.18., SzÉNÁSI V.

Tychius flavus BECKER, 1864 - lucernamag-tímárormányos - Vác, Naszály, sejcei gyümölcsös, fühálózás, 2021.VI.18., SzÉNÁSI V.

Köszönetnyilvánítás. A szerzök köszönik az amatör rovarászoknak és a www.izeltlabuak.hu weboldal használóinak, hogy a Naszályon általuk gyüjtött vagy megfigyelt bogárfajok adatait a rendelkezésünkre bocsátották. Köszönet illeti az MTM Állattára Bogárgyüjteményének jelenlegi és korábbi munkatársait, név szerint GRABANT ARANKÁT és SZABÓ CSILLÁT, akik a gyüjtésekben közremüködtek.

\section{Irodalomjegyzék}

100/2012. (IX. 28.) VM rendelet A védett és a fokozottan védett növény- és állatfajokról, a fokozottan védett barlangok köréről, valamint az Európai Közösségben természetvédelmi szempontból jelentős növény- és állatfajok közzétételéröl szóló 13/2001. (V. 9.) KöM rendelet és a növényvédelmi tevékenységről szóló 43/2010. (IV. 23.) FVM rendelet módosításáról. Magyar Közlöny, 128: 20903-21019. http://www.kozlonyok.hu/nkonline/MKPDF/hiteles/mk12128.pdf

DE JONG Y. et al. 2014. Fauna Europaea - all European animal species on the web. Biodiversity Data Journal, 2: e4034. https://fauna-eu.org/about (utolsó megtekintés: 2021. nov. 21.)

ENDRÖDI S. 1963. Ormányosbogarak III. - Curculionidae III. In: Magyarország Állatvilága (Fauna Hungariae), X, 6. Akadémiai Kiadó, Budapest, 104 pp.

Horvatovich S. 2007. Ritka bogárfajok (Coleoptera) a Dél-Dunántúl bükköseiböl. A Janus Pannonius Múzeum Évkönyve, 50-52: 59-66. https://doi.org/10.2753/0577-5132500204

Kippenberg H. 1981. Die mitteleuropäischen Arten der Gattung Plinthus Germ. Entomologische Blätter, 76: 73-140.

KonvičKa O. \& MerkL O. 2015. First records of Phloiotrya rufipes (Coleoptera: Melandryidae) in Hungary, with a national checklist of the family. Folia entomologica hungarica, 76: 107-114. https://doi.org/10.17112/FoliaEntHung.2015.76.1

Kovács T., Magos G. \& URBÁN L. 2010. Ritka és természetvédelmi szempontból jelentős rovarok (Insecta) a Mátra és Tarnavidék területéről II. Folia historico-naturalia Musei Matraensis, 34: 181-195. 
KovÁCs T. \& NÉMETH T. 2010. Ritka szaproxilofág bogarak Magyarországról (Insecta: Coleoptera). (Rare saproxylic species from Hungary). Folia historico-naturalia Musei Matraensis, 34: 133-139.

KÖDÖвÖCZ V. 2017. A sátoraljaújhelyi Kazinczy Ferenc Múzeum futóbogár gyüjteménye (Coleoptera: Carabidae). Folia historico-naturalia Museum Matraensis, 41: 79-154.

KÖRMENDY Z. 2021a. Fényesnyakú zsákbogár. Forrás: izeltlabuak.hu, licenc: CC BY 4.0 https://www.izeltlabuak.hu/talalat/197622 (utolsó megtekintés: 2021. nov. 29.)

KÖRMENDY Z. 2021b. Tarka tölgyormányos. Forrás: izeltlabuak.hu, licenc: CC BY 4.0 https://www.izeltlabuak.hu/talalat/197656 (utolsó megtekintés: 2021. nov. 29.)

LAWRence J. F. \& Newton A. F. Jr. 1995. Families and subfamilies of Coleoptera (with selected genera, notes, references and data on family-group names). In: PAKALUK J. \& ŚLIPIŃSKI S. A. (ed.): Biology, phylogeny, and classification of Coleoptera: Papers celebrating the 80th birthday of Roy A. Crowson. Muzeum i Instytut Zoologii Pan, Warszawa, pp. 779-1006.

MERKL O. 2010. A Naszály bogárfaunája (Coleoptera). In: PINTÉr B. \& TímÁr G. (szerk.): A Naszály természetrajza. Tanulmánygyüjtemény. Rosalia (A Duna-Ipoly Nemzeti Park Igazgatóság tanulmánykötetei, 5.) Duna-Ipoly Nemzeti Park Igazgatóság, Budapest, pp. 533-639.

MerkL O. \& Vig K. 2009. Bogarak a Pannon régióban. Vas Megyei Múzeumok Igazgatósága, B. K. L. Kiadó, Magyar Természettudományi Múzeum, Szombathely, 494 pp.

MOLNÁR M.-NÉ 2018. Laposszemü busaormányos. Forrás: izeltlabuak.hu, licenc: CC BY 4.0 https://www.izeltlabuak.hu/talalat/29907 (utolsó megtekintés: 2021. nov. 29.)

Németh T., Merkl O., Romsauer J., Seres G. \& Szalóki D. 2017. New country records and confirmed occurrences of beetles in Hungary (Coleoptera). Folia entomologica hungarica, 78: 27-34. https://doi.org/10.17112/FoliaEntHung.2017.78.27

Palaga M. 2021. Mezei élősdibogár. Forrás: izeltlabuak.hu, licenc: CC BY 4.0 https://www.izeltlabuak.hu/talalat/173541 (utolsó megtekintés: 2021. nov. 29.)

PAULIK P. 2021. Bordáshátú földiormányos. Forrás: izeltlabuak.hu, licenc: CC BY 4.0 https://www.izeltlabuak.hu/talalat/183814 (utolsó megtekintés: 2021. nov. 29.)

PinTÉr B. \& TímÁr G. 2010. A Naszályról általában. In: PinTér B. \& TímÁr G. (szerk.): A Naszály természetrajza. Tanulmánygyüjtemény. Rosalia (A Duna-Ipoly Nemzeti Park Igazgatóság tanulmánykötetei, 5.) Duna-Ipoly Nemzeti Park Igazgatóság, Budapest, pp. 11-16.

Podlussány A. 2007. A Bakony ormányosbogár-faunája (Coleoptera: Brachyceridae, Curculionidae). A Bakony természettudományi kutatásának eredményei 30. - Bakonyi Természettudományi Múzeum, Zirc, 224 pp.

SzALÓKi D. 1996. Cantharoidea, Cleroidea and Lymexyloidea (Coleoptera) from the Bükk National Park. In: Mahunka S. (szerk.): The Fauna of the Bükk National Park, II. Hungarian Natural History Museum, Budapest, pp. 263-270.

SzÉNÁSI V. 2020. Further new and rare weevils in Hungary (Coleoptera: Curculionidae). Folia entomologica hungarica, 81: 81-86. https://doi.org/10.17112/FoliaEntHung.2020.81.81

WiEZIK M., KunCA V. \& WiEZIKOvÁ A. 2015. Mass occurrence of relict beetle species Endecatomus reticulatus (Herbst, 1973) and Leiestes seminiger (Gyllenhall, 1808) associated with rare saproxylic fungi. Proceedings of the conference "Roubal's Days I», Banská Bystrica, 27. 1. 2015. Matthias Belivs University Proceedings (Biological Serie), 5(Suppl. 2): 83-91.

Zhou L. W., VlASÁK J. Jr. \& VlASÁK J. 2014. Inonotus andersonii and I. krawtzewii: another case of molecular sequencing-based diagnosis of morphologically similar species. Chiang Mai Journal of Science, 41(4): 789-797. 


\title{
New beetles of Naszály Hill
}

\section{OTTÓ MERKL ${ }^{1} \uparrow$, VALENTIN SZÉNÁSI $^{2}$, BALÁZS PINTÉR ${ }^{3}$ \& TAMÁS NÉMETH ${ }^{4}$ *}

\author{
${ }^{1}$ Hungarian Natural History Museum, Baross utca 13, H-1088 Budapest, Hungary \\ ${ }^{2}$ Duna-Ipoly National Park Directorate, Költő utca 21, H-1021 Budapest, Hungary \\ ${ }^{3}$ Institute of Experimental Medicine Laboratory of Molecular Neurobiology, Szigony utca 43, H-1083 Budapest, \\ Hungary \\ ${ }^{4}$ Hungarian University of Agriculture and Life Sciences Department of Zoology and Ecology, Páter Károly utca 1, \\ H-2100 Gödöllö, Hungary \\ *E-mail: haesito@gmail.com
}

ÁLLATTANI KÖZLEMÉNYEK (2022) 107(1-2): 000-000.

\begin{abstract}
The study describes the beetle species newly found on the Naszály Hill in the Vác region since 2010. During the past 11 years 123 species have been found here as new for the fauna of Naszály (eight of them are protected), thus amounting to a total number of 1408 beetle species. Several of these newly found species are rarities in the fauna of Hungary. Endecatomus reticulatus is very infrequent throughout Europe, its record on the Naszály is its fifth proven occurrence in Hungary.
\end{abstract}

Keywords: biodiversity, Coleoptera, HUDI20038, Hungarian Natural History Museum, nature conservation, saproxylic

Accepted: 04.01.2022

Published online: 14.01 .2022 